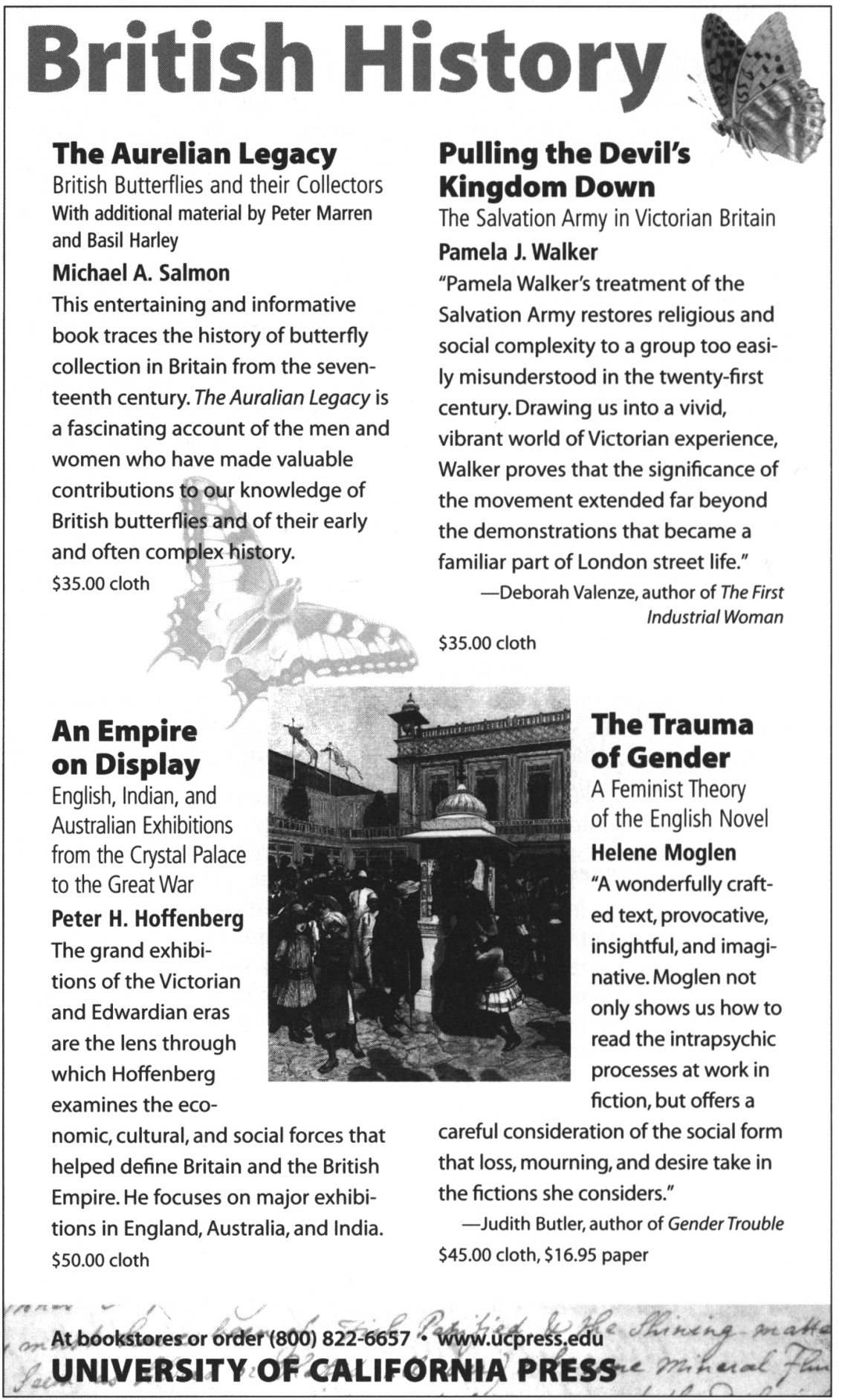


E ssays and photographs celebrating

E the breadth, diversity, and delicacy of the English countryside.

Essays by Christopher Lloyd, Marina Warner, David Bellamy, the Duchess of Devonshire, and Richard Mabey, among other distinguished writers.
Viking Studio
448 pp.
0-670-89680-2
$\$ 39.95$
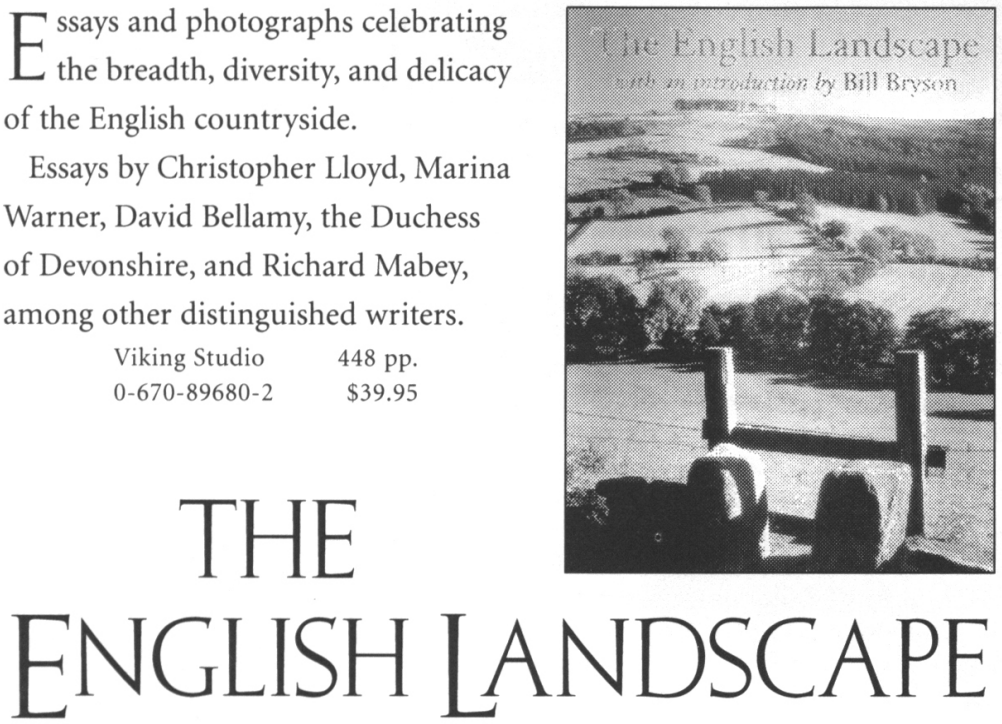

I NTRODUCTION BY BILL BRYSON

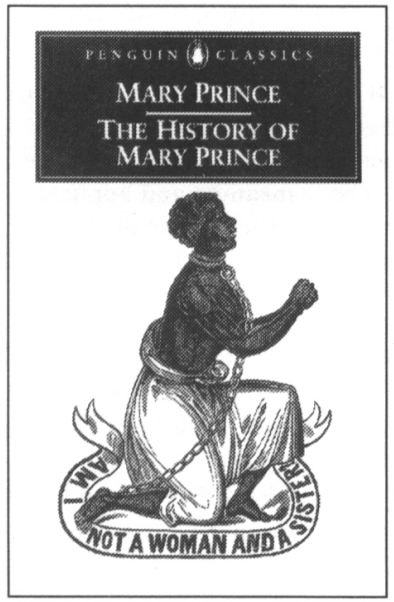

$\triangle$ fter enduring years of abuse at the hands owned her, Mary Prince traveled to London in 1828. There she dictated the story of her life, which became a potent instrument for the Anti-Slavery Society.

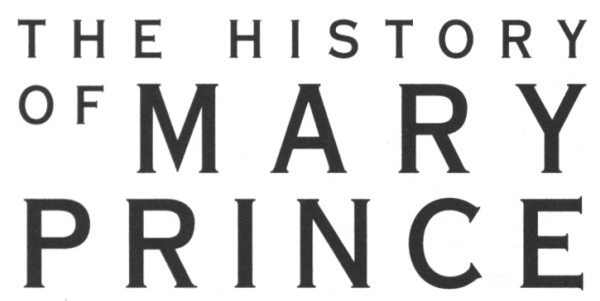

EDITED WITH AN INTRODUCTION AND NOTES BY S A R A S A L I H

Penguin Classic $\quad 160 \mathrm{pp} \quad 0-14-043749-5 \quad \$ 12.00$ 
Pedagogical Economies The Examination and the Victorian Literary Man

\section{CATHY SHUMAN}

This book explores the examination's figurative power for 19th-century discourses of subject formation and value through readings of works by Matthew Arnold, Anthony Trollope, Charles Dickens, and John Ruskin, writers who were active in the 1850 s and $1860 \mathrm{~s}$, when the examination began to structure a range of British institutions, from the working-class primary school to the Indian Civil Service.

$\$ 45.00$ cloth

\section{Townspeople and Nation \\ English Urban \\ Experiences, 1540-1640}

ROBERT TITTLER

"We know much more about the court and the country in early modern England than we do about urban society and life. What Tittler ... does successfully in this fine and innovative book, is to tell us about this relatively hidden England and to give it a human face by discussing specific individual lives." -Paul S. Seaver, Stanford University $\$ 19.95$ paper $\$ 60.00$ cloth

\section{Protestant Identities}

Religion, Society, and Self-Fashioning in PostReformation England

Edited by MURIEL C. MCCLENDON, JOSEPH P. WARD, AND MICHAEL MACDONALD

Assessing the English Reformation's legacy of increasing religious diversification, this book explores the complex ways in which England's gradual transformation from a Roman Catholic to a Protestant nation presented men and women with new ways in which to define their relationships with society.

$\$ 55.00$ cloth

\section{Singular Continuities}

Tradition, Nostalgia, and Identity in Modern British Culture

\section{Edited by GEORGE} K. BEHLMER AND FRED M. LEVENTHAL This volume explores the appropriation of the past in modern British culture. The twelve essays argue that to distinguish between "the new" and "the traditional" today often draws a false dichotomy. It argues that Britishness, in fact, has been the product of continuous creation throughout the 19 th and 20th centuries. $\$ 55.00$ cloth

\section{The Boxmaker's} Revenge

'Orthodoxy,' 'Heterodoxy,' and the Politics of the Parish in Early Stuart London

PETER LAKE

By narrating a protracted and frequently bizarre altercation between a London minister and a member of his flock, this book provides a vivid picture of puritanism at the parish level in early Stuart England, and places this dispute in the multiple social, cultural, and political contexts necessary to understand it.

$\$ 24.95$ paper $\$ 65.00$ cloth

\section{The Royal Navy, Seapower and Strategy Between the Wars}

\section{CHRISTOPHER M. BELL}

This is the first study to show how the Royal Navy's ideas about the meaning and application of seapower shaped its policies in the interwar period. It challenges the accepted view that the shortcomings of Britain's naval leaders resulted in poor strategic planning and an inability to meet the challenges of World War II. $\$ 51.00$ cioth

\section{British History from}

\section{Sutanerisoitrolpress}

$800 \cdot 872 \cdot 7423 \quad w w w \cdot s u p=0 r g$

"The Stanford University Press site is superbly designed." - The Journal of Electronic Publishing 


\section{NEW FROM CAMBRIDGE}

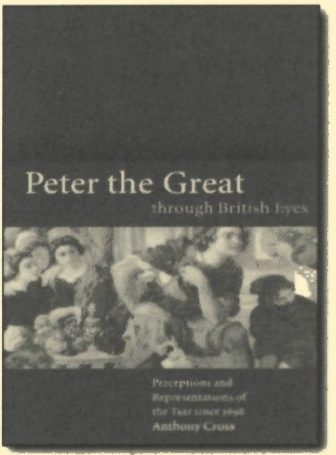

Peter the Great through British Eyes

Perceptions and Representations of the Tsar since 1698

Anthony Cross

0-521:78298-8 Hardback \$54.95

\section{Aliens in Medieval Law}

The Origins of Modern Citizenship

Keechang Kim

Cambridge Studies in English Legal History

0-521-80085-4 Hardback \$64.95

\section{Reginald Pole}

Prince and Prophet

Thomas F. Mayer

0-521-37188-0 Hardback \$74.95

\section{The Cambridge Urban History of Britain}

Volume I: c. 600 -c. 1540

D.M. Palliser, Editor

Cambridge Urban History of Britain 1

0-521-44461-6 Hardback \$140.00

The Grammar of Empire in Eighteenth-Century British Writing

Janet Sorensen

0-521-65327-4 Hardback $\$ 59.95$

Available in bookstores or from

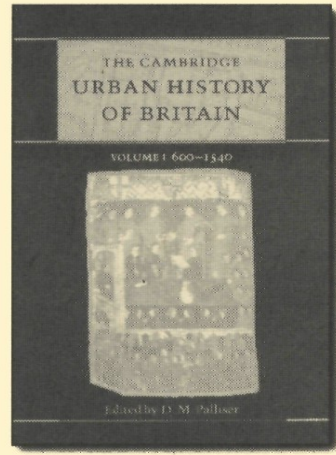

The Church in an Age of Danger

Parsons and Parishioners, 1660 - 1740

Donald A. Spaeth

Cambridge Studies in Early Modern British Hiśtory

0-521-35313-0 Hardback \$64.95

The Rise and Fall of State-Owned Enterprise in the Western World Pier Angelo Toninelli, Editor

Comparative Perspectives in Business History 1 0-521-78081-0 Hardback \$49.95

\section{Reading History in Early Modern} England

D.R. Woolf

Cambridge Studies in Early Modern British History

0-521-78046-2 Hardback \$69.95

\section{Spreading Germs}

Disease Theories and Medical Practice in Britain, 1860-1900

Michael Worboys

Cambridge Studies in the History of Medicine

0-521-77302-4 Hardback \$59.95

Now in paperback...

Prayer Book and People in Elizabethan and Early Stuart England

Judith Maltby

Cambridge Studies in Early Modern British History

0-521-79387-4 Paperback \$22.95 


\section{BRITISH STUDIES}

NEW FROM CHICAGO

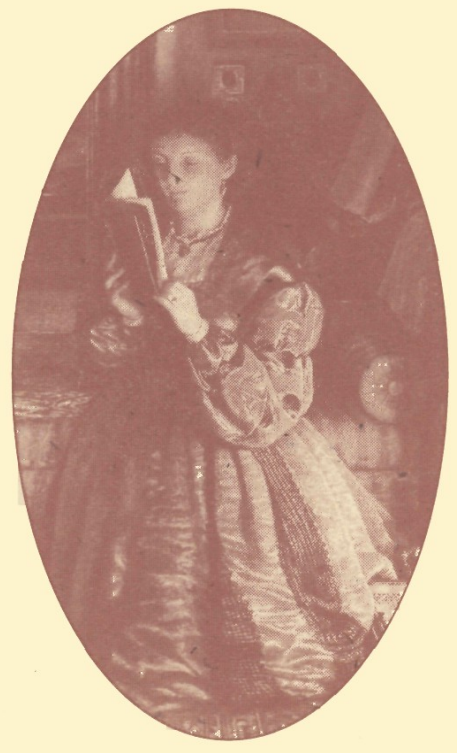

Victorian SENSATION

The Extraordinary Publication, Reception, and Secret Authorship of Vestiges of the Natural History of Creation

JAMIES A. SECORD

"Victorian Sensation is a spectacularly successful reorientation of the history of popular science. James Secord's fine-meshed study of the controversial Vestiges of the Natural History of Creation is so rich in detail that at times you almost smell' the hearth fires burning as readers deliberate. It is nothing short of a masterpiece-a stunning evocation of the making of evolutionary culture which sets the historical standard for the new millennium."

LAdrian Desmond; author of Huxly: From Devil's Disciple to Evolution's High Priest CLOTr $\$ 35.00$

\section{THE NOTORIOUS ASTROLOGICAL \\ PHYSICIAN OF LONDON}

Works and Days of Simon Forman Barbara howaro Traisiter

"Barbara Howard Traister has given us a wonderfully three-dimensional portrait of the weird, fascinating figure of Simon Forman. Physician, astrologer, and magician, Forman left a remarkably full manuscript record of his professional practices, obsessions, researches, dreams, intrigues, and sexyal adventures. Traister's rich account enables us to venture into the hidden redersises of Elizatbethan and Jacobean culture." -Stephen Greenblatt, coauthor

Small Change

Women, Learning. Patriotism, 1750-1810

\section{HARRIET GUEST}

"This book provides a host of original insights into the gender dimension of eighteenth-century British patriotism. ... Careful studies of leading writers like Elizabeth Carter, Anna Barbauld, and Mary Wollstonecraft show very clearly how the 'small change' of womanhood was meant to have very large political consequences." -Barbara Taylor, author of Eve and the New Jerusalem

PAPER \$20.00 of Practicing New Historicism Com $\$ 30.00$
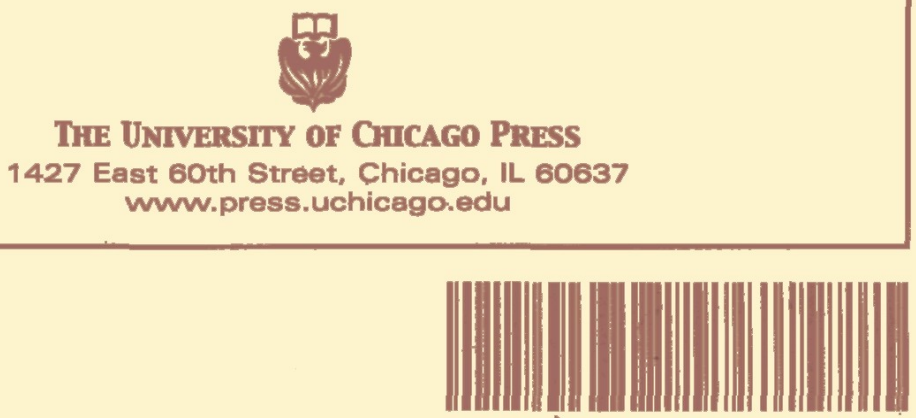

0021-9371(200104)40:2;1-\# 